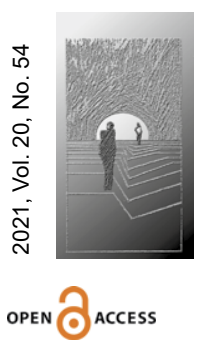

Ilona Dąbrowska

http://orcid.org/0000-0001-7451-2648 Uniwersytet Marii Curie-Skłodowskiej w Lublinie

i.dabrowska@poczta.umcs.lublin.pl DOI: $10.35765 / h w .2036$

\title{
Edukacja zdalna w czasie pandemii - perspektywa rodziców i opiekunów
}

\section{STRESZCZENIE:}

CEL NAUKOWY: Celem artykułu jest poznanie opinii rodziców oraz opiekunów na temat organizacji i przebiegu edukacji zdalnej w czasie pandemii wirusa SARS-CoV-2 w Polsce.

PROBLEM I METODY BADAWCZE: W prezentowanym artykule analizom poddano wypowiedzi rodziców odnoszące się do edukacji zdalnej prowadzonej w czasie pandemii. Wykonano analizę dostępnych raportów i publikacji, jak również przeprowadzono badania własne (ankietowe).

PROCES WYWODU: Zdefiniowano kluczowe dla analizy pojęcia oraz przedstawiono wyniki badań ankietowych.

WYNIKI ANALIZY NAUKOWEJ: Przeprowadzona analiza wykazała nie tylko niską ocenę realizowanych zajęć, ale także wskazała konkretne płaszczyzny, gdzie konieczne jest wprowadzenie nowych rozwiązań, a wręcz systemowego wsparcia merytorycznego czy psychologicznego.

WNIOSKI, INNOWACJE, REKOMENDACJE: Przedstawione w pracy wyniki badań potwierdzają tezę o zwiększeniu liczby zadań i obowiązków, które nakłada na rodziców edukacja zdalna. Wyniki badań dostarczają informacji o konkretnych potrzebach, tak objętych zdalną edukacją uczniów, jak i organizujących opiekę w domu rodziców.

$\rightarrow$ SŁOWA KLUCZOWE: PANDEMIA, SARS-COV-2, EDUKACJA ZDALNA, E-LEARNING, WYCHOWANIE

\section{ABSTRACT}

\section{Remote Education During Pandemic - Parents' and Guardians' Perspective}

SCIENTIFIC OBJECTIVE: The aim of the article is to find out the opinions of parents and guardians on the organization and course of remote education during the SARS-CoV-2 virus pandemic in Poland. 


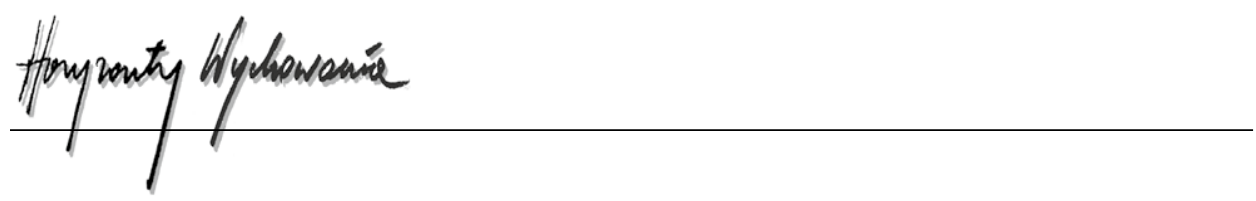

PROBLEM AND RESEARCH METHODS: In the presented article, parents' statements regarding remote education during the pandemic were analyzed. An analysis of the available reports and publications was performed, as well as own (questionnaire) research.

THE PROCESS OF ARGUMENTATION: The key concepts for the analysis were defined and the results of the questionnaire were presented.

RESULTS OF SCIENTIFIC ANALYSIS: The conducted analysis showed not only a low evaluation of the activities carried out, but also indicated specific areas where it is necessary to introduce new solutions, and even substantive or psychological systemic support.

CONCLUSIONS, INNOVATIONS, RECOMMENDATIONS: The research results presented in the paper confirm the thesis about increasing the number of tasks and responsibilities imposed on parents by remote education. The research results provide information on the specific needs of both students covered by remote education and those who organize care at home.

\section{$\rightarrow$ KEYWORDS: PANDEMIC, SARS-COV-2, REMOTE EDUCATION, E-LEARNING, RAISING}

\section{Wstęp}

Pojawienie się wirusa SARS-CoV-2 tak w Polsce, jak i na całym świecie wywołało niepokój, napięcie społeczne oraz lęk. „Nowa normalność” stała się z dnia na dzień faktem, a wraz z nią niepewność jutra i utrudnienia w codziennym funkcjonowaniu. Ograniczenia związane z pandemią przyniosły ogromne zmiany dla niemal każdej dziedziny życia. Jedną z nich jest edukacja. Od momentu wprowadzenia w kraju stanu epidemiologicznego sytuacja uczniów oraz ich rodziców pozostaje dynamiczna. Tym samym ogromny ciężar opieki oraz wsparcia realizacji procesu edukacyjnego online spoczywa właśnie na rodzicach. Dlatego też warto dokładniej przyjrzeć się ocenom oraz odczuciom, jakie w tej grupie społecznej wzbudza edukacja zdalna. Przedmiotem artykułu jest ocena organizacji oraz przebiegu procesu edukacji i opieki nad dziećmi w wieku szkolnym w czasie pandemii wirusa SARS-CoV-2 w Polsce przez rodziców i opiekunów dzieci w wieku szkolnym. Tym samym stanowi próbę odpowiedzi na pytanie o adekwatność i funkcjonalność aktualnie przyjętych rozwiązań, mających na celu kontynuowanie nauki w czasie trwającej pandemii. Rozważania kończą propozycje rekomendacji, których uwzględnienie w procesie planowania i realizowania e-learningu w przyszłości mogłoby przynieść wymierne korzyści zarówno dla nauczycieli, rodziców i opiekunów, jak i samych uczniów.

\section{Metody i narzędzia badawcze}

W niniejszej pracy obok analizy piśmiennictwa specjalistycznego przedstawiono wyniki badań własnych dotyczących organizacji opieki oraz procesu edukacji zdalnej dla dzieci 
i młodzieży w wieku szkolnym. Przeprowadzone badania miały charakter ilościowy, a dobór osób poddanych badaniu był losowy. Narzędzie badawcze stanowiła ankieta, którą respondenci rozwiązywali w trybie on-line. W badaniu wzięły udział 132 osoby, reprezentujące niemal wszystkie regiony kraju. Należy dodać, że w badaniu wziąć udział mógł jedynie rodzic (ojciec lub matka) bądź opiekun prawny, pod którego opieką znajduje się minimum jedno dziecko będące w wieku szkolnym (od szóstego do osiemnastego roku życia). Uczestnicy wypełniali ankietę on-line, która składała się z dwunastu pytań. Badanie cechowała całkowita anonimowość, a sporządzona ankieta zawierała w sobie jedynie kilka pytań, które pozwoliły na osadzenie badanych w przestrzeni takiej jak: województwo, forma opieki nad dzieckiem, liczba dzieci w wieku szkolnym przebywających pod opieką respondenta czy wiek dzieci w wieku szkolnym. Badanie przeprowadzono w lutym 2021 roku. Główne pytanie badawcze brzmiało: Jak edukację zdalną (e-learning oraz przyjęte rozwiązania organizacyjne) oceniają rodzice i opiekunowie dzieci w wieku szkolnym? Sformułowano pytania pomocnicze, które podzielono na dwie grupy. W pierwszej z nich umieszczono zagadnienia dotyczące procesu zdalnego nauczania, takie jak: (1) ocena edukacji zdalnej, (2) pozytywne i negatywne strony edukacji zdalnej, (3) zmiany w zachowaniu i emocje dzieci w związku z e-learningiem. Druga grupa pytań związana jest z organizacją opieki dla dzieci w domu: (4) sposoby zapewniania opieki dzieciom podczas zdalnego nauczania, (5) organizacja czasu wolnego, (6) wyzwania, problemy i potrzeby rodziców i opiekunów. Każda z osób biorących udział w badaniu po wypełnieniu metryczki wypełniała ankietę on-line, odpowiadając na następujące pytania jednostkowe: (1) Czy pandemia spowodowała zmianę Pani/ Pana formy pracy na zdalną lub hybrydową?, (2) Kto zapewnia/zapewniał opiekę Pani/ Pana dziecku/dzieciom w czasie pandemii, kiedy szkoły są/były zamknięte?, (3) Które z określeń najlepiej opisuje to, jak Pani/Pana dzieci spędzają czas w dobie pandemii?, (4) Jak Pani/Pan ocenia naukę zdalną?, (5) Jakie pozytywne strony nauki zdalnej Pani/ Pan dostrzega?, (6) Jakie negatywne strony nauki zdalnej Pani/Pan dostrzega?, (7) Czy podczas okresu nauki zdalnej zauważyła Pani/Pan zmiany u dziecka? Jakie?, (8) Jakie emocje u Pani/Pana wzbudza edukacja zdalna?, (9) Jakie emocje u Pani/Pana dziecka/ dzieci wzbudza edukacja zdalna?, (10) Jakie wyzwania/problemy stanęły przed Panią/ Panem podczas edukacji zdalnej?, (11) Jaka forma nauczania byłaby w Pani/Pana opinii najlepsza w czasie pandemii?, (12) Jaka pomoc byłaby Pani/Pana rodzinie najbardziej przydatna w czasie nauki zdalnej? Zebrane odpowiedzi zostały opracowane, odpowiedzi podliczone i skategoryzowane.

\section{E-learning w Polsce}

Anglojęzyczny termin e-learning w dosłownym tłumaczeniu oznacza „elektroniczne uczenie się”. W Polsce wymiennie stosowane bywa także: „nauczanie elektroniczne”, „e-nauczanie” czy „nauka on-line”. Wszystkie te określenia odnoszą się do tego samego procesu, tj. techniki szkolenia na odległość, w której wiedza jest zdobywana, a umiejętności są 


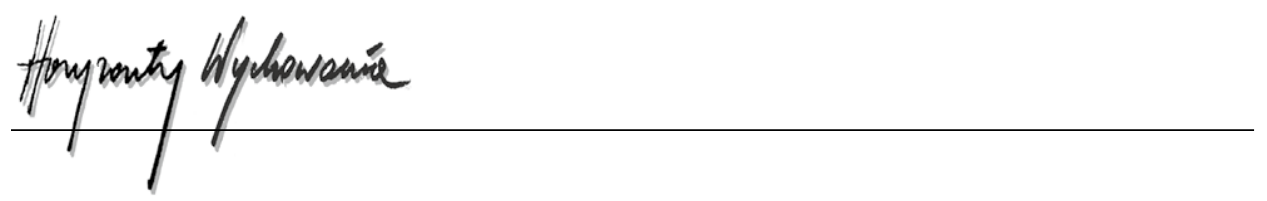

rozwijane z zastosowaniem najnowszych technologii i narzędzi informatycznych (Pluta-Olearnik, 2006, s. 8). Rozwój nowych technologii umożliwił powstanie oraz upowszechnienie tzw. platform e-learningowych, czyli zestawów oprogramowania umożliwiających prowadzenie zajęć w trybie on-line. Popularnym w tym kontekście terminem jest także „wirtualne środowisko kształcenia” (ang. Virtual Learning Environment - VLE). Pojęcie to ma charakter bardziej ogólny, a swoim zakresem obejmuje całość procesów związanych z nauczaniem on-line (Dąbrowski, 2013, s. 206). Do realizacji zdalnego nauczania wykorzystywane są rozmaite platformy edukacyjne. Są to systemy komputerowe pozwalające organizować i wspomagać nauczanie przez internet. Określane bywają także skrótem LMS (ang. Learning Management System). Podstawowe funkcjonalności tych systemów pozwalają gromadzić materiały dydaktyczne, organizować je czy udostępniać odbiorcom przez internet. Platformy e-learningowe są rozbudowanymi aplikacjami ułatwiającymi tworzenie, prowadzenie oraz administrowanie kursami edukacyjnymi. Są to, inaczej mówiąc, zintegrowane zestawy narzędzi pozwalające realizować konkretne cele edukacyjne, umożliwiają zarządzaniem kursem i wchodzącymi w jego skład zasobami (Molga, 2015, s. 135).

Jak piszą Michał Kozioł oraz Michał Woźniak, e-learning jest metodą zdobywania wiedzy (techniką nauczania i sposobem uczenia się) z wykorzystaniem mediów elektronicznych. Proces ten najkrócej określić można jako uczenie się przez internet. Tak pojmowany e-learning obejmuje niemal każdy rodzaj i sposób internetowego uczenia się - także w oderwaniu od instytucji edukacyjnych czy nauczycieli (Woźniak i Kozioł, 2012, s. 184). Na ten sam aspekt zwraca uwagę Katarzyna Włodarczyk, która zaznacza, że terminem e-learning można określić wszelkie formy szkoleń, wykorzystujące media elektroniczne, gdzie kontakt osobisty z nauczycielem jest ograniczony do minimum (Włodarczyk, 2015, s. 401). Część badaczy akcentuje wagę roli nauczyciela, opisując ją jako przewodzenie w samodzielnych poszukiwaniach (Adamowicz i Pyra, 2018, s. 78). Nauczanie za pomocą platformy e-learningowej nie oznacza uproszczenia treści kształcenia, zmniejszenia atrakcyjności zajęć czy mniejszych nakładów czasu. Wręcz przeciwnie - prowadzący powinien posiadać konkretne kompetencje w zakresie zasad komunikacji w sieci, tworzenia prezentacji bądź grafik (Wach-Kąkolewicz i Shelest, 2014, s. 59).

Ważnym terminem, który warto zaakcentować, jest tzw. blended learning (b-learning), czyli hybrydowa metoda kształcenia, łącząca tradycyjne metody nauki z aktywnościami on-line. Jak zaznacza Adam Stecyk, nowoczesne e-nauczanie prowadzone jest on-line lub off-line w wewnętrznej sieci placówki szkolącej (intranet) lub poprzez sieć zewnętrzną (internet), często z wykorzystaniem dodatkowych zasobów na nośnikach informacji (CD-ROM, DVD itp.). Rozwój aplikacji mobilnych oraz rozpowszechnienie smartfonów wśród młodszych grup wiekowych pozwala przenosić nauczanie także na poziom telefonu - m-learning, ang. mobile learning (Stecyk, 2009, s. 373).

Raport „Edukacja zdalna w czasie pandemii”, wydany przez Fundację Centrum Cyfrowe w listopadzie 2020 roku, dostarcza informacji dotyczących oceny edukacji zdalnej przez nauczycieli realizujących ją w omawianym okresie. Autorzy publikacji piszą 
m.in., że pandemia odsłoniła problem niskich kompetencji cyfrowych nauczycielek/li, te mają być jednak konsekwencją braku szkoleń i wsparcia merytorycznego w tym zakresie (Buchner i Wierzbicka, 2020). W lutym 2021 roku opublikowano komunikat z badań Centrum Badania Opinii Społecznej dotyczący edukacji zdalnej w Polsce. Na pytanie o ocenę jakości zdalnego nauczania aż $62 \%$ respondentów (rodziców) wskazało, że jej jakość jest zdecydowanie gorsza od nauki prowadzonej w trybie stacjonarnym (Omyła-Rudzka, 2021, s. 6). Ważki problem obciążenia emocjonalnego w kontekście trwającej pandemii podjęli Wiesław Poleszak i Jacek Pyżalski. Badacze zwrócili uwagę na fakt, że samopoczucie młodego człowieka zależy od indywidualnych cech, dlatego też myśląc o sytuacji młodzieży w czasach pandemii koronawirusa, należy mieć na uwadze, że nie jest ona jednorodna (Poleszak i Pyżalski, 2020). Warto zaznaczyć, że izolacja i brak wsparcia rówieśniczego, monotonia, konieczność samodzielnej pracy nad materiałem szkolnym, wreszcie długotrwałe przebywanie wśród domowników stanowią wyzwalacze kryzysów (Bilicki, 2020).

W grudniu 2020 roku publikowano raport Obawy rodziców i nauczycieli wobec nowych form edukacji w okresie pandemii SARS-CoV-2. Studium województwa śląskiego wykonany na zlecenie Stowarzyszenia Biznes - Nauka - Samorząd „Pro Silesia”, a zrealizowany przez naukowców z Instytutu Nauk Politycznych Wydziału Nauk Społecznych Uniwersytetu Śląskiego. Większość biorących udział w badaniu $(66,4 \%)$ wyrażała zaniepokojenie wynikające z niskiej jakości pracy zdalnej oraz kompetencji informatycznych nauczycieli. Najwięcej obaw wśród respondentów $(70,8 \%)$ budziła jednak perspektywa trudności w realizacji podstawy programowej w warunkach nauczania zdalnego (Turska-Kawa i in., 2020, s. 9).

\section{Edukacja zdalna w czasie pandemii - perspektywa rodziców}

Jednym z pierwszych pytań zadanych podczas przeprowadzanych badań była prośba o wystawienie oceny nauce zdalnej. Respondenci dysponowali sześciostopniową skalą, gdzie cyfra 6 oznaczała ocenę najwyższą (wzorową), 5 - bardzo dobrą, 4 - dobrą, 3 - dostateczną, 2 - złą, 1 - bardzo złą. Największą grupę, liczącą 29\% wszystkich respondentów, stanowili rodzice oceniający proces edukacji zdalnej na trójkę - dostatecznie. Druga pod względem liczebności była grupa 33 osób (25\%), którzy edukacji zdalnej wystawili ocenę dobrą, a grupa licząca 32 respondentów e-naukę oceniła źle. Co ważne, ocenę najniższą (1) wskazało 15\% wszystkich badanych, tym samym uznać należy, że łączna grupa rodziców negatywnie oceniających proces zdalnego nauczania (źle i bardzo źle) stanowi prawie $40 \%$ wszystkich badanych. W celu uzyskania informacji odnośnie pozytywnych stron e-naucznia, respondenci odpowiadali na pytanie: „Jakie pozytywne strony nauki zdalnej Pani/Pan dostrzega?”. Podczas gdy część rodziców wymieniała jedną, dwie lub więcej cech, inni wyznali, że nie dostrzegają ich wcale. Wyróżniono następujące grupy odpowiedzi: (1) nie dostrzegam żadnych, (2) rozwinięcie kompetencji komputerowych, (3) dłuższy sen dziecka, (4) większa samodzielność dziecka, (5) oszczędność 


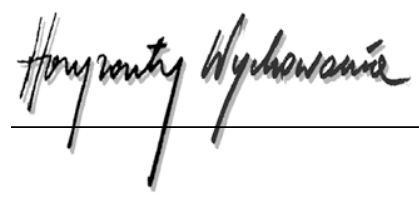

czasu (brak konieczności dowożenia do szkoły), (6) bieżące informacje na temat zadań szkolnych i postępów w nauce, (7) brak pośpiechu, (8) mniej stresu, (9) więcej czasu z rodziną, (10), mniej przeziębień, infekcji, chorób, (11) ochrona przed zakażeniem wirusem SARS-CoV-2, (12) inne. Największą grupę spośród badanych stanowią rodzice, którzy wskazali, że nie dostrzegają żadnych pozytywnych stron zdalnego nauczania. Takiej odpowiedzi udzieliły 53 osoby, co stanowi niemal połowę wszystkich respondentów. Spośród rodziców, którzy zauważyli pewne pozytywne strony e-nauczania, największa część wyznała, że dziecko rozwinęło swoje komputerowe umiejętności (15 respondentów), dłużej i lepiej śpi (14 odpowiedzi), stało się bardziej samodzielne (12). Rodzice zwrócili też uwagę na oszczędność czasu związaną z brakiem konieczności dowożenia dziecka do placówek szkolnych czy otrzymywanie bieżących informacji na temat aktualnego tematu zajęć i postępów w nauce. Rozważając zagadnienie pozytywnych stron zdalnego nauczania, równie zasadne wydaje się pytanie o negatywne strony tego procesu. Na podstawie zebranych danych wyróżnić można było konkretne grupy negatywnych stron, jakie zauważają rodzice. Największą z nich stanowią odpowiedzi wskazujące na izolację społeczną oraz brak kontaktu z rówieśnikami (75 odpowiedzi), drugą pod względem liczby odpowiedzi stanowi grupa rodziców akcentująca niższy poziom nauczania niż w przypadku nauki stacjonarnej, a także nieprzygotowanie nauczycieli do prowadzenia lekcji w trybie on-line (34 odpowiedzi), w następnej kolejności respondenci wskazali: apatię, znużenie i brak motywacji do nauki (32 odpowiedzi), zbyt dużą ilość czasu spędzaną przez komputerem, w tym nie tylko podczas e-lekcji (27), zbyt mało ruchu oraz brak zajęć z wychowania fizycznego (21), zbyt dużo prac domowych i materiału do samodzielnego przyswojenia (17), konieczne wsparcie rodziców podczas nauki (12), utrudniony kontakt z nauczycielem (9), wady postawy, bóle głowy, wady wzroku (6). Wyraźne wskazanie izolacji społecznej oraz braku kontaktu z rówieśnikami warto rozpatrywać także w kontekście zdrowia psychicznego uczniów. Ten problem zaznaczają przywoływane we wcześniejszych rozdziałach raporty. Niewątpliwie przymusowa i nagła izolacja dzieci i młodzieży przyczynia się do pogorszenia ich samopoczucia jest w stanie wywołać m.in. apatię czy brak motywacji do nauki. W konsekwencji przedłużania się lockdownu uczniowie tracą możliwości spędzania czasu z przyjaciółmi na zasadach, które były im do tej pory znane, i w sposób, jaki sprawiał im przyjemność. Mimo że e-learning pozwala na prowadzenie rozmów (także w formie wideo), nie zaspokaja potrzeby obcowania z drugim człowiekiem. Tym samym stwierdzić należy, że technologie mające za zadanie „przedłużanie” naszych możliwości stanowią niedoskonały substytut spotkań i relacji, które znamy z rzeczywistości niewirtualnej. W celu bardziej szczegółowej analizy zadano pytanie o ewentualne zmiany w zachowaniu dzieci. Na pytanie: „Czy podczas okresu nauki zdalnej zauważyła Pani/Pan zmiany u dziecka? Jakie?" 20 osób spośród respondentów wskazało, że nie dostrzegło żadnych zmian u podopiecznych. Spośród osób, którzy odpowiedziały twierdząco, wskazywano kolejno na: apatię, znużenie, brak motywacji, problemy z koncentracją (53 osoby), stres, napięcie, nerwowość, lęk, rozdrażnienie (50 odpowiedzi), tęsknotę za rówieśnikami, kolegami i koleżankami (13 osób), brak sportu, ruchu, niechęć do jakiejkolwiek aktywności 
czy wyjścia z domu (12), trudności w relacjach społecznych, wycofanie się (11), mniej stresu, mniej pośpiechu, lepszy sen, apetyt (10), więcej czasu przed komputerem, konsolą, więcej gier komputerowych (9), gorsze wyniki w nauce, mniejsza wiedza (6), problemy ze wzrokiem, kręgosłupem, bóle głowy (3), dziecko jest zadowolone z nauki zdalnej (3). Nietrudno dostrzec, że w centrum uwagi respondentów po raz kolejny widoczne są u podopiecznych problemy ze sferą psychologiczną.

Na pytanie o to, jakie emocje wzbudza u Pani/Pana edukacja zdalna, większość rodziców wskazała, że są one raczej negatywne - 37\%; kolejne wybory: neutralne (25\%), negatywne $(20 \%)$, bardzo negatywne $(13 \%)$, raczej pozytywne $(2 \%)$, pozytywne $(2 \%)$, bardzo pozytywne (2\%). Łączna suma odpowiedzi wskazujących na pozytywne emocje wynosi tym samym zaledwie $6 \%$ przy $25 \%$ odpowiedzi wskazujących emocje neutralne i aż $70 \%$ odpowiedzi mówiących o negatywnych emocjach. W kolejnym pytaniu rodzice zapytani zostali o ocenę emocji ich dzieci w kontekście zdalnego nauczania. Dostrzec można pewne różnice w ocenie sytuacji przez dzieci. Na pytanie o to, jaka forma nauczania byłaby zdaniem rodziców najlepsza w obecnej sytuacji, zdecydowana większość respondentów (49\%) wskazała na naukę stacjonarną. Druga pod względem liczby odpowiedzi jest grupa rodziców, według których nauka hybrydowa jest optymalnym rozwiązaniem (29\%), natomiast tak dla nauki zdalnej powiedziało $17 \%$ badanych.

\section{Organizacja opieki w domu}

Brak możliwości uczęszczania dzieci do placówek szkolnych i uruchomienie procesu edukacyjnego w trybie nauki zdalnej wiążą się z konkretnymi konsekwencjami. Nie dotyczą one wyłącznie samego aspektu edukacyjnego, ale także kwestii organizacji opieki w domu. Interesującym zagadnieniem wydaje się zatem pytanie tak o zmiany w organizacji życia opiekunów (rodziców), jak i samych podopiecznych. W toku prowadzonych badań sformułowano pytanie o formy pracy rodziców i opiekunów w związku z sytuacją epidemiologiczną i wprowadzeniem nauczania zdalnego. Jak wykazała ankieta, największą grupę stanowią rodzice, którzy od momentu pojawienia się pandemii pracują hybrydowo (41\%). Druga najczęściej wskazywana odpowiedź to utrzymanie formy pracy sprzed pandemii - tj. praca poza miejscem zamieszkania (30\%). Zmianę formy pracy na wyłącznie zdalną wskazało 18\% respondentów. W grupie respondentów znaleźli się także rodzice, którzy tak przed jak i w czasie trwającej pandemii nie pracowali zawodowo (9\%), a najmniejszą grupę stanowiły osoby, które już przed pandemią pracowały zdalnie bądź hybrydowo, i tryb ten utrzymały w czasie zagrożenia epidemiologicznego (2\%). Warto przypomnieć, że ankietę wypełniał każdorazowo wyłącznie jeden z rodziców, aby uzyskać zatem pełniejszy obraz dotyczący sprawowania opieki nad dziećmi w czasie nauki zdalnej, sformułowano pytanie: „Kto zapewnia/zapewniał opiekę Pani/ Pana dziecku/dzieciom w czasie pandemii, gdy szkoły są/były zamknięte?”. Większość badanych wskazała, że funkcję opiekuna przejmuje rodzic pracujący w trybie zdalnym (44\%), w drugiej kolejności zaznaczano konieczność pozostawiania dziecka samego 


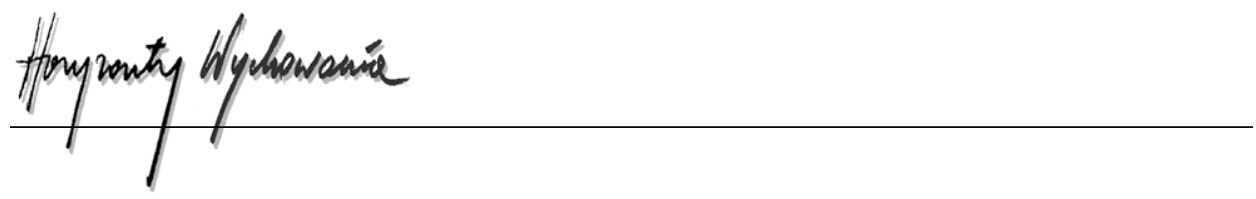

w domu (29\%), trzecią grupę stanowili rodzice, którzy do opieki nad pozostającym w domu dzieckiem angażują członków rodziny (np. babcię, dziadka czy ciocię) - 16\%, a u $9 \%$ wszystkich respondentów dzieckiem zajmuje się jedno z rodziców, które nie pracuje zawodowo (zajmuje się domem, jest na urlopie, rencie bądź zwolnieniu lekarskim). Mając na uwadze problem opieki nad dzieckiem pozostającym w domu, zasadne wydaje się pytanie o sposoby spędzania czasu. W tym celu ankietowani poproszeni zostali o wskazanie określeń, które najlepiej opisują formy spędzania czasu ich dzieci w dobie pandemii. Respondenci mogli zaznaczyć więcej niż jedną odpowiedź lub sformułować własną. Zdecydowana większość biorących udział w badaniu rodziców, bo aż 90 ze 132 osób, przyznała, że okres zdalnej nauki oznacza więcej czasu spędzanego przed telewizorem lub konsolą (z zaznaczeniem, że nie jest to czas nauki, a rozrywki). W drugiej kolejności rodzice wskazywali na pojawianie się większej liczby nerwowych sytuacji, w trzeciej - więcej nauki niż przed pandemią. Zestawiając omawiane wyniki z zaznaczonymi we wcześniejszej części problemami dotyczącymi złego psychicznego samopoczucia podopiecznych, wnioskować można, że zwiększenie ilości czasu spędzanego przed telewizorem lub konsolą nie poprawia nastroju dzieci i młodzieży. Ta forma rozrywki, choć powszechnie lubiana i jakże popularna, okazuje się przynosić znacznie mniejsze korzyści dla zdrowia psychicznego niż np. spotkania rówieśnicze. W toku prowadzonych badań zebrano odpowiedzi na pytanie o to, jakie problemy i wyzwania pojawiały (i w dalszym ciągu pojawiają) się najczęściej. Widoczne jest wyróżnienie trzech głównych grup problemów, z jakimi borykali się rodzice. Największa grupa respondentów (46 osób) wskazała na konieczność pomagania dzieciom podczas zdalnej nauki - zarówno w momencie trwania e-lekcji (szczególnie najmłodszym dzieciom, które nie radziły sobie jeszcze z obsługą komputera), jak i w czasie wolnym od zajęć, kiedy uczeń miał samodzielnie wykonać zadanie domowe lub przyswoić materiał. Nieznacznie mniejszą pod względem liczebności była grupa 42 rodziców, dla których największe wyzwanie stanowiło łączenie pracy zawodowej z opieką nad dzieckiem. Podobną liczbę (40) zebrano dla odpowiedzi mówiącej o problemach z zapewnieniem sprzętu, internetu czy miejsca do nauki. Ten problem pojawiał się zwykle w sytuacji, gdy w domu znajdowało się troje i więcej dzieci uczących się zdalnie. Pojawiły się także odpowiedzi wskazujące na problemy ze zmobilizowaniem dziecka do nauki (10 osób), zapewnieniem opieki dziecku pozostającemu w domu (10 osób), problemy emocjonalne dziecka, takie jak zwiększona nerwowość czy apatia (10 osób), problemy zdrowotne (2 osoby). Istotne w tym kontekście wydaje się pytanie o potrzeby tak rodziców, jak i samych uczniów w czasie trwającej pandemii. $Z$ tego też powodu respondenci zapytani zostali o to, jaka pomoc byłaby ich rodzinie najbardziej przydatna w czasie nauki zdalnej. Uzyskane odpowiedzi jednoznacznie wskazują, że pierwszą, najpowszechniejszą potrzebą jest wsparcie merytoryczne (np. korepetytor lub dodatkowe konsultacje z nauczycielami), zaakcentowało je 50 osób. Niewiele mniej, bo 46 osób wyznało, że najbardziej potrzebne jest im wsparcie psychologiczne, 35 potrzebuje sprzętu komputerowego do nauki zdalnej, 33 umożliwienia pracy zdalnej, 30 opiekunki/opiekuna do dzieci, a 27 wsparcia technicznego do komputera lub internetu. 


\section{Podsumowanie wyników badań}

Edukacja zdalna, mimo że kierowana bezpośrednio do uczniów, często staje się dodatkowym obowiązkiem dla pozostałych członków rodziny - najczęściej rodziców. Przeprowadzone badania wskazują, że obecnie realizowany w Polsce proces e-nauczania spotyka się z niską oceną wystawianą mu przez rodziców. Rodzice nie dostrzegają korzyści płynących z nauczania zdalnego, wymieniają natomiast wiele negatywnych skutków, spośród których najczęściej powtarzany jest problem izolacji społecznej dzieci i braku kontaktu z rówieśnikami, jak również niższy poziom nauczania, znużenie, apatia i brak motywacji dzieci do nauki. Jednym ze sposobów wsparcia opiekunów w tym zakresie mogłoby być opracowanie przewodników (w dowolnej formie), które krok po kroku tłumaczyłyby pojęcia bądź prezentowały przykładowe ćwiczenia pozwalające utrwalić zdobyte podczas e-learningu informacje. Dobrym rozwiązaniem byłyby także spotkania (konsultacje) rodziców z nauczycielami przedmiotowymi, podczas których omawiano by ewentualne wątpliwości.

Biorąc pod uwagę konieczność stacjonarnego pobierania nauki w trybie on-line, a zarazem potrzebę wzmacniania odporności organizmu, sport oraz kształtowanie zdrowych nawyków (także żywieniowych) powinny być traktowane priorytetowo. Tymczasem analiza wyników badań dostarczyła informacji świadczących o braku bądź znacznym skracaniu czasu trwania zajęć wychowania fizycznego. Skoro współczesne rozwiązania technologiczne (m.in. aplikacje mobilne) umożliwiają zindywidualizowane treningi sportowe, dlaczego by nie zaimplementować ich w procesie krzewienia kultury fizycznej? Niewątpliwie duże znaczenie w tym zakresie ma podejście oraz umiejętności cyfrowe samego nauczyciela przedmiotu. Odwołując się do jednej z przytoczonych we wcześniejszej części tekstu definicji e-learningu mówiącej, że jest to proces nauczania skoncentrowany na uczniu (Adamowicz i Pyra, 2018, s. 78), należy podkreślić, że to właśnie uczeń powinien być w centrum zainteresowania. Wszelkie metody i narzędzia, po które sięgamy w procesie edukacyjnym, powinny odpowiadać obecnym potrzebom uczniów. Fakt istnienia aplikacji umożliwiających przeprowadzanie zdalnych sprawdzianów czy testów wiedzy nie oznacza, że uczeń drugiej klasy szkoły podstawowej będzie w stanie taką aplikację obsłużyć. Tymczasem w opiniach rodziców biorących udział w badaniu nie brakuje wypowiedzi wskazujących na niedostosowanie sposobu prezentowania treści (bądź sprawdzania wiedzy) do poziomu umiejętności cyfrowych dzieci. Brak optymalizacji wykorzystywanych w procesie edukacji zdalnej narzędzi skutkuje niepokojem, stresem, wycofaniem, a nawet lękiem.

Nowa edukacyjna rzeczywistość i związane z nią wyzwania rodzą konkretne potrzeby. Wyniki przeprowadzonych badań wyraźnie akcentują obszary, które w kontekście prowadzonej obecnie edukacji zdalnej wymagają ulepszenia bądź wsparcia. Warto zastanowić się nad pytaniem o możliwości i formy pomocy, jaką należałoby skierować w stronę rodziców i ich podopiecznych. Dobrym kierunkiem wydaje się także zaangażowanie w proces wsparcia rodziców jak największej liczby podmiotów tak jednostek szczebla ministerialnego, samorządowego, jak i organizacji pozarządowych czy podmiotów prywatnych. Jednocześnie dostrzegalny jest deficyt spójnej strategii, która powinna stanowić pierwszy krok na drodze do ulepszenia procesu zdalnej edukacji w Polsce. Mimo że bezprecedensowa 


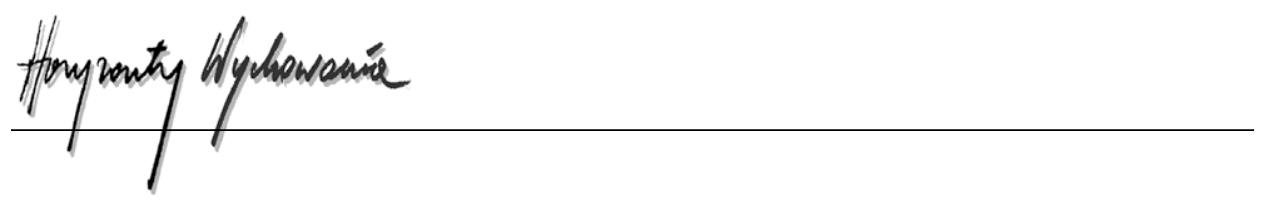

sytuacja pandemiczna usprawiedliwia początkowy chaos, mamy już za sobą niemal rok doświadczeń. Popularyzacja wiedzy i dobrych praktyk z zakresu realizacji i wsparcia procesu e-edukacji wydaje się dzisiaj słusznym i potrzebnym działaniem.

\section{BIBLIOGRAFIA}

Adamowicz, M. i Pyra, M. (2018). Skuteczność e-learningu i jego opłacalność w obszarze logistyki. Zeszyty Naukowe Uniwersytetu Przyrodniczo-Humanistycznego w Siedlcach, 45(118), 77-82.

Bilicki, T., (2020). Jak pracować z uczniem w kryzysie w czasie pandemii COVID-19. W: J. Pyżalski (red.), Edukacja w czasach pandemii wirusa COVID-19. Z dystansem o tym, co robimy obecnie jako nauczyciele (s. 16-24). Warszawa: EduAkcja.

Buchner, A. i Wierzbicka, M. (2020). Edukacja zdalna w czasie pandemii. Warszawa: Fundacja Centrum Cyfrowe. https://centrumcyfrowe.pl/wp-content/uploads/sites/16/2020/11/Raport_Edukacja-zdalna-w-czasie-pandemii.-Edycja-II.pdf

Dąbrowski, M. (2013), E-learning w szkolnictwie wyższym. Studia BAS, 35(3), 203-211.

Molga, A. (2015), Platformy e-learningowe oraz ich znaczenie dla procesu kształcenia. Dydaktyka Informatyki, 10, 133-139.

Omyła-Rudzka, M. (2021). Edukacja zdalna - doświadczenia i oceny. Komunikat z badań CBOS, 19. https://cbos.pl/SPISKOM.POL/2021/K_019_21.PDF

Pluta-Olearnik, M. (2006). Rozwój usług edukacyjnych w erze społeczeństwa informacyjnego. Warszawa: Polskie Wydawnictwo Ekonomiczne.

Poleszak, W. i Pyżalski, J. (2020). Psychologiczna sytuacja dzieci i młodzieży w dobie epidemii. W: J. Pyżalski (red.), Edukacja w czasach pandemii wirusa COVID-19. Z dystansem o tym, co robimy obecnie jako nauczyciele (s. 7-15). Warszawa: EduAkcja.

Stecyk, A. (2009), E-learning i blended learning w edukacji. Charakterystyka projektu LAMS WZiEU, W: Z. Zioło i T. Rachwał (red.), Rola przedsiębiorczości w kształtowaniu społeczeństwa informacyjnego (s. 373-380). Warszawa-Kraków: Wydawnictwo Nowa Era. https://doi. org/10.24917/20833296.5.32

Turska-Kawa, A., Stępień-Lampa, N. i Grzywa P. (2020). Obawy rodziców i nauczycieli wobec nowych form edukacji w okresie pandemii SARS-CoV-2. Studium Województwa Śląskiego. Katowice: Biznes - Nauka - Samorząd „Pro Silesia”. DOI:10.13140/RG.2.2.27224.32004

Wach-Kąkolewicz, A. i Shelest, O. (2014), Wyzwolić zaangażowanie, czyli o konstruktywizmie w e-learningu. W: J. Antoszkiewicz i M. Rocki (red.), E-edukacja w praktyce - wyzwania i bariery (s. 55-65). Warszawa: Fundacja Promocji i Akredytacji Kierunków Ekonomicznych.

Włodarczyk, K. (2015), E-learning jako element lifelong learning. Przykład społeczeństwa polskiego. Zeszyty Naukowe Uniwersytetu Szczecińskiego. Studia i Prace Wydziału Nauk Ekonomicznych i Zarządzania, 39(3), 397-409.

Woźniak, M. i Kozioł, M. (2012). Kryteria i metody oceny efektywności szkoleń e-learningowych. Zeszyty Naukowe Małopolskiej Wyższej Szkoły Ekonomicznej w Tarnowie, 21(2), 181-195.

\section{Copyright and License}

This article is published under the terms of the Creative Commons Attribution - NoDerivs (CC BY- ND 4.0) License http://creativecommons.org/licenses/by-nd/4.0/ 